PATIK : Jurnal Hukum

https://ejournal.uhn.ac.id/index.php/patik

Volume 06 Nomor 01, April 2020 Page : 51 - 59

p-issn : $2086-4434$

\title{
ANALISIS YURIDIS TERHADAP PRAKTEK PERJANJIAN TERTUTUP AIR MINUM DALAM KEMASAN (STUDI PUTUSAN NOMOR 22/KPPU-I/2016)
}

\author{
Fitri Oktaviani Sihombing, Eritah Wage Wati Sitohang, Lesson Sihotang \\ Fakultas Hukum, Universitas HKBP Nommensen \\ eritahwage_sitohang@uhn.ac.id
}

\begin{abstract}
Abstrak
Penelitian ini bertujuan untuk menganalisis analisa hukum terhadap pertimbangan majelis hakim dalam memberikan putusan pada perkara Nomor 22/KPPU-I/2016. Penelitian ini menggunakan analisa yuridis dan studi kepustakaan. Dalam penelitian kepustakaan, studi pustaka dilakukan pada peraturan perundang-undang dan studi pustaka lainnya, pengumpulan data dengan mengadakan studi penelaahan terhadap buku-buku, literatur-literatur, yang ada hubungannya dengan masalah. Data yang diperoleh kemudian dianalisis menggunakan pendekatan yuridis dan dijabarkan dengan deskriptif analitis. Berdasarkan hasil penelitian, penulis menyimpulkan bahwa PT Balina Agung Perkasa dan PT Tirta Investama telah melakukan praktek perjanjian tertutup dan penguasaan pasar karena telah melanggar pasal 15 ayat (3) huruf b dan pasal 19 huruf a dan b yakni adanya penguasaan pasar dan perjanjian tertutup.
\end{abstract}

Kata kunci: Analisis Yuridis, Praktek Perjanjian Tertutup, Air Minum Dalam Kemasan

\begin{abstract}
This study aims to analyze the legal analysis of the judges' considerations in making decisions on case Number 22 / KPPU-I / 2016. This research uses juridical analysis and literature study. In library research, literature study is carried out on statutory regulations and other literature studies, collecting data by conducting study studies of books, literature, which have to do with the problem. The data obtained were then analyzed using a juridical approach and described by analytical descriptive. Based on the results of the research, the authors conclude zthat PT Balina Agung Perkasa and PT Tirta Investama have practiced closed agreements and market control because they have violated article 15 paragraph (3) letter $b$ and article 19 letters $a$ and $b$, namely the existence of market control and closed agreements.
\end{abstract}

Keywords: Constitutional Court, judicial preview, jurisdiction 


\section{PATIK : JURNAL HUKUM Vol : 09 No. 1 April 2020, Hal 51 - 59}

\section{Pendahuluan}

Pemenuhan kebutuhan air minum sendiri sangat tergantung pada faktor cakupan layanan air minum pada masyarakat baik dalam proses pengelolaan, pendistribusian dan konsumsi air minum. Target pemenuhan Air Minum Indonesia pada tahun 2015 adalah 70\% sesuai dengan komitmen para Pemimpin Dunia di Johannesburg pada Summit 2002. Komitmen yang menghasilkan "Millenium Development Goals"(MDGs) ini menyatakan bahwa pada tahun 2015 separuh penduduk dunia yang saat ini belum mendapatkan akses terhadap air minum (Save Drinking Water) harus telah mendapatkannya. Sedang pada tahun 2015 seluruh penduduk dunia harus telah mendapatkan akses terhadap air minum. ${ }^{1}$

Untuk mewujudkan harapan dan cita-cita dalam Summit 2002 tersebut tentunya tidak lepas dari upaya para pelaku usaha dalam dunia industri air mineral sehingga mereka terlibat dalam persaingan usaha yang sangat ketat. Dampak baiknya bagi persaingan usaha ini setiap pelaku usaha akan memberikan yang terbaik dalam produk atau jasanya, dan konsumen mempunyai pilihan dalam membeli produk atau jasa tersebut dengan harga murah tetapi kualitas sangat baik. Persaingan dalam dunia usaha seharusnya dipandang sebagai suatu hal yang positif. Namun dengan berjalannya perkembangan usaha yang pesat, para pelaku usaha tidak sedikit yang melakukan persaingan usaha dengan tidak sehat demi meraup keuntungannya sendiri. ${ }^{2}$

Era globalisasi saat ini membuat para pelaku pasar semakin bersaing untuk mendapatkan keuntungan yang lebih luas. Agar mendapatkan keuntungan yang maksimal, pelaku usaha terkadang bahkan sering melakukan tindakan yang kurang bahkan tidak jujur yang dapat menghambat pelaku usaha lain dalam melaksanakan prinsip ekonominya. Salah satu bentuk persaingan usaha tidak sehat yaitu perjanjian tertutup dan penguasaan pasar. Dalam Undang-Undang Nomor 5 tentang Larangan Praktek Monopoli dan Persaingan Usaha Tidak Sehat telah dijelaskan bahwa perjanjian bukan hanya dalam bentuk tulisan akan tetapi juga perbuatan-perbuatan yang membuat hilangnya persaingan, pembatasan produksi dan peningkatan harga. ${ }^{3}$

Salah satu contoh perbuatan monopoli maupun perjanjian yang dilarang adalah Pelaku usaha membuat perjanjian mengenai harga atau potongan harga tertentu atas barang dan atau jasa, yang memuat persyaratan bahwa pelaku usaha yang menerima barang dan atau jasa dari pelaku usaha pemasok tidak akan membeli barang dan atau jasa yang sama atau sejenis dari pelaku usaha lain yang menjadi pesaing dari pelaku usaha pemasok. ${ }^{4}$

Pelaku usaha dilarang melakukan satu atau beberapa kegiatan, baik sendiri maupun bersama pelaku usaha lain, yang dapat mengakibatkan terjadinya praktek monopoli dan atau persaingan usaha tidak sehat berupa menolak dan atau menghalangi pelaku usaha tertentu untuk melakukan kegiatan usaha yang sama pada pasar bersangkutan atau menghalangi konsumen atau pelanggan pelaku usaha pesaingnya untuk tidak melakukan hubungan usaha dengan pelaku usaha pesaingan yaitu. ${ }^{5}$

Hal tersebut di atas termuat dalam putusan nomor 22/KPPU-I/2016. Dalam putusan nomor 22/KPPU-I/2016, dapat dilihat adanya praktik monopoli maupun perjanjian yang

\footnotetext{
${ }^{1}$ Rohim, Miftahur. 2006. Tesis:Analisis Penerapan Metode Kaporitisasi Sederhana Terhadap Kualitas Bakteriologis Air PAM. (Semarang: Universitas Diponegoro). http://eprints.undip.ac.id/15727/1/Miftahur_Rohim.pdf.

${ }^{2}$ L. Budi Kagramanto, Mengenal Hukum Persaingan Usaha Berdasarkan UU Nomor 5 Tahun 1999, 2008, (Surabaya: Laros), Hlm. 16.

3 Ditha Wiradiputra, Perjanjian Dilarang, Bahan Mengajar Hukum Persaingan Usaha, 2008, (Depok: Hukum Universitas Indonesia)

${ }^{4}$ Undang-Undang Nomor 5 tahun 1999 tentang Larangan Praktik Monopoli dan Persaingan Usaha , Pasal 15 ayat (3) huruf $b$

${ }^{5}$ Ibid, Pasal 19 huruf a dan b
} 
dilarang. Kasus yang terjadi merupakan masalah antara PT. Tirta Investama dan PT. Balina Agung Perkasa. Bahwa PT TIV dan PT BAP secara bersama-sama pernah menyampaikan himbauan lisan kepada para pedagang Star Outlet (SO) mulai dari akhir tahun 2015 sampai dengan pertengahan tahun 2016, PT TIV melalui KAE dan PT BAP melalui bagian penjualan. Dengan bukti dokumen mengenai "Form Sosialisasi Pelanggan Star Outlet" yang memerintahkan bahwa penjual yang menjadi Star Outlet dari produk PT TIV bersedia untuk tidak menjual produk air minum dalam kemasan (AMDK) dengan merek Le Minerale, dan bersedia menerima konsekuensi sanksi dari PT TIV berupa penurunan ke Wholeseller apabila menjual produk kompetitor sejenis dengan merek Le Minerale. Kemudian Form Sosialisasi Pelanggan Star Outlet tersebut ditandatangani oleh pedagang SO lengkap dengan nama pemilik dan nomor telepon dan form tersebut disebarkan baik secara bersama-sama maupun sendiri-sendiri oleh pegawai PT TIV dan/atau PT BAP.

Majelis Komisi menilai, menganalisa, menyimpulkan dan memutuskan Perkara Nomor 22/KPPU-I/2016, yang diputus pada tanggal 19 Desember 2017, PT Tirta Investama dan PT Balina Agung Jaya terbukti bersalah dan melanggar Pasal 15 ayat (3) huruf b dan Pasal 19 huruf a dan b Undang-Undang Nomor 5 Tahun 1999 tentang Larangan Praktik Monopoli dan Persaingan Usaha Tidak Sehat. Dalam perkara antara PT. Tirta Fresindo Jaya melawan PT Tirta Investama dan PT Balina Agung Jaya, Majelis Komisi menghukum PT Tirta Investama selaku Terlapor I untuk membayar denda sebesar Rp.13.845.450.000,00 dan PT Balina Agung Jaya selaku Terlapor II sebesar Rp.6.294.000.000,00 untuk disetorkan ke kas negara.

Berdasarkan uraian latar belakang tersebut, maka dapat dirumuskan permasalahan Bagaimana analisis hukum terhadap pertimbangan majelis hakim dalam memberikan putusan pada perkara Nomor: 22/KPPU-I/2016?

\section{Tinjauan Pustaka}

Perjanjian tertutup adalah suatu perjanjian yang dibuat oleh pelaku usaha agar dapat menjadi sarana dan upaya bagi pelaku usaha untuk dapat melakukan pengendalian oleh pelaku usaha terhadap pelaku usaha lain secara vertikal ("Pengendalian Vertikal"), baik melalui pengendalian harga maupun melalui pengendalian non-harga. ${ }^{6}$ Exclusive agreement (perjanjian tertutup) merupakan perjanjian antara pelaku usaha selaku pembeli dan penjual untuk melakukan kesepakatan secara eksklusif yang dapat berakibat menghalangi dan menghambat pelaku usaha lain untuk melakukan kesepakatan yang sama, salah satunya dengan penetapan harga. ${ }^{7}$

Perjanjian tertutup merupakan bagian dari salah satu bentuk perjanjian yang dilarang dalam hukum persaingan usaha, perjanjian tertutup diatur dalam Pasal 15 UU No. 5 Tahun 1999. Perjanjian tertutup (exclusif dealing) adalah suatu perjanjian yang terjadi antara mereka yang berada pada level yang berbeda pada proses produksi atau jaringan distribusi suatu barang atau jasa yang terdiri dari Exclusif Distribution Agreement, Tying Agreement, dan Vertical Agreement on Discount. Strategi perjanjian tertutup ini pada umumnya lebih banyak dilakukan pada level distribusi produk barang dan/atau jasa. Pada konteks perjanjian tertutup, pada umumnya pelaku usaha bersedia menerima persaingan antar produk yang bersaing yang dihasilkan oleh produsen yang berbeda pada pasar yang sama (interbrand competition) yang ketat, tetapi kemudian secara sangat kuat

${ }^{6}$ Peraturan Komisi Pengawas Persaingan Usaha Nomor 5 Tahun 2011 tentang Pedoman Pasal 15 UU No. 5 Tahun 1999

${ }^{7}$ PeraturanKomisiPengawasPersainganUsahaNomor5Tahun2011 tentangPedomanPasal15(Perjanjian Tertutup)Undang-UndangNomor5Tahun1999tentangLaranganPraktekMonopoli dan Persaingan Usaha TidakSehat 
mengendalikan persaingan antar distributor (intrabrand competition). Ekslusif dealing atau perjanjian tertutup ini terdiri dari: ${ }^{8}$

Hukum persaingan usaha memiliki dua pendekatan yaitu pendekatan per se illegal dan rule of reason. Pendekatan per se illegal adalah menyatakan setiap perjanjian atau kegiatan usaha tertentu sebagai ilegal, tanpa pembuktian lebih lanjut atas dampak yang ditimbulkan dari perjanjian atau kegiatan usaha tersebut. Kegiatan yang dianggap per se illegal biasanya meliputi penetapan harga secara kolusif atas produk tertentu, serta pengaturan harga penjualan kembali. Sebaliknya pendekatan rule of reason adalah suatu pendekatan yang digunakan oleh lembaga otoritas persaingan usaha untuk membuat evaluasi mengenai akibat perjanjian atau kegiatan usaha tersebut bersifat menghambat atau mendukung persaingan. ${ }^{9}$ Pendekatan yang terdapat pada hukum persaingan usaha akan dipaparkan lebih lanjut. Per se adalah larangan yang bersifat jelas, tegas dan mutlak dalam memberi kepastian bagi para pelaku usaha. Larangan ini bersifat tegas dan mutlak disebabkan perilaku yang sangat mungkin merusak persaingan sehingga tidak perlu lagi melakukan pembuktian akibat perbuatan tersebut. Per se illegal yaitu pendekatan dimana suatu perjanjian atau kegiatan usaha dilarang karena dampak dari perjanjian telah dianggap jelas dan pasti mengurangi atau menghilangkan persaingan. Dalam pendekatan ini pelaku usaha pelapor tidak perlu membuktikan adanya dampak suatu perjanjian yang dibuat pelaku usaha pesaingnya. $^{10}$

Menurut Dr. Sutrisno Iwantono, MA, dalam tulisannya yang berjudul "Per Se Illegal dan Rule Of Reason dalam Hukum Persaingan Usaha" yang dimaksud dengan pendekatan per se illegal adalah suatu perbuatan yang secara inheren bersifat dilarang atau illegal. Terhadap suatu perbuatan atau tindakan atau praktek yang bersifat dilarang atau illegal tanpa perlu pembuktian terhadap dampak dari perbuatan tersebut. ${ }^{11} \mathrm{Per}$ se illegal dapat juga diartikan sebagai suatu terminologi yang menyatakan bahwa suatu tindakan dinyatakan melanggar hukum dan dilarang secara mutlak, serta tidak diperlukan pembuktian mengenai apakah tindakan tersebut memiliki dampak negatif terhadap persaingan usaha. ${ }^{12}$ Per se illegal merupakan suatu pendekatan dimana suatu perjanjian atau suatu kegiatan bersama dilarang karena dampak dari perjanjian tersebut telah dianggap jelas dan pasti mengurangi atau menghilangkan persaingan. Oleh karena itu, dalam pendekatan ini pelaku usaha pelapor tidak perlu membuktikan adanya dampak suatu perjanjian yang dibuat oleh pelaku usaha pesaingnya. Bukti yang diperlukan adalah bahwa perjanjian yang dimaksud telah benar adanya bahwa kegiatan bisnis yang dimaksud telah benar-benar dilakukan oleh pelaku usaha pesaingnya. ${ }^{13}$

Penerapan dengan pendekatan per se illegal membawa manfaat besar bagi penegakan hukum persaingan usaha, karena pendekatan per se illegal mudah dan mempunyai kejelasan dalam proses administratif. Per se illegal yang dianggap mudah, karena memperkenankan keadilan menolak melakukan penyelidikan secara rinci yang memerlukan banyak waktu, biaya mahal untuk mencari fakta di pasar yang bersangkutan. ${ }^{14}$ Dalam Undang-Undang Nomor 5 Tahun 1999 tentang Larangan Praktek Monopoli

8 Andi Fahmi Lubis, Anna Maria Anggraini, dkk, Hukum Persaingan Usaha Antara Teks dan Kontex, 2009, (Jakarta: ROV Creative Media), Hlm. 118.

${ }^{9}$ Op.Cit,Andi Fahmi Lubis, Hlm. 55

${ }^{10}$ Mustafa Kamal Rokan, Hukum Persaingan Usaha Teori Praktiknya di Indonesia, 2012, (Jakarta: Raja Grafindo Persada), Hlm. 60

${ }^{11}$ Hermansyah, Pokok-Pokok Hukum Persaingan Usaha di Indonesia, 2008, (Jakarta: Kencana), Hlm. 78

\footnotetext{
${ }^{12}$ Ibid

${ }^{13}$ Ibid

${ }^{14}$ Op.Cit, Rahmadi Usman, Hlm. 177-178
} 


\section{PATIK : JURNAL HUKUM Vol : 09 No. 1 April 2020, Hal 51 - 59}

dan/atau Persaingan Usaha Tidak Sehat, teori per se illegal diterapkan pada Pasal-Pasal yang tidak mensyaratkan "yang mengakibatkan atau dapat mengkibatkan terjadinya praktek monopoli dan/atau persaingan usaha tidak sehat". Perbuatan-perbuatan seperti perjanjian penetapan harga, perjanjian pemboikotan dan perjanjian pembagian wilayah adalah contoh jenis-jenis perbuatan yang diklafikasikan sebagai per se illegal. ${ }^{15}$

Pendekatan rule of reason adalah kebalikan per se illegal. Pendekatan rule of reason terhadap perbuatan yang dituduhkan melanggar hukum persaingan harus mempertimbangkan situasi dan kondisi kasus, karena perbuatan yang dituduhkan tersebut harus diteliti lebih dahulu apakah perbuatan tersebut telah membatasi persaingan secara tidak patut. Perbuatan yang diteliti dahulu, maka penggugat disyaratkan dapat menunjukkan akibat yang ditimbulkan dari perjanjian, kegiatan, dan posisi dominan yang telah menghambat persaingan atau menyebabkan kerugian.

Pendekatan rule of reason adalah suatu pendekatan yang menentukan meskipun suatu perbuatan telah memenuhi rumusan Undang-Undang, namun jika ada alasan objektif yang dapat membenarkan perbuatan tersebut, maka perbuatan itu bukan merupakan suatu pelanggaran. Artinya penerapan hukumnya tergantung pada akibat yang ditimbulkannya, apakah perbuatan itu telah menimbulkan praktek monopoli dan atau persaingan usaha tidak sehat, karena titik beratnya adalah unsur materiil dan perbuatannya. Jadi penerapan hukum dalam pendekatan rule of reason mempertimbangkan alasan-alasan mengapa dilakukannya suatu tindakan atau suatu perbuatan oleh pelaku usaha.

Dalam Undang-Undang Nomor 5 Tahun 1999 ini telah mengatur mengenai tata cara penanganan perkara sebagaimana ditentukan dalam Pasal 38 sampai dengan Pasal 46 yang kemudian diimplementasikan lebih lanjut dengan Peraturan Komisi Pengawas Persaingan Usaha No. 01 Tahun 2006 tentang Tata Cara Penanganan Perkara di KPPU ini adalah pengganti dan menyempurnakan Keputusan Komisi Pengawas Persaingan Usaha N0.05/KPPU/KEP/IX/2000 Tahun 2000 Tentang Tata Cara Penyampaian Laporan dan Penanganan Dugaan Pelangagaran Terhadap Undang-Undang Nomor 5 tahun 1999. Sanksi-sanksi yang akan dijatuhkan terhadap pelaku usaha yang melanggar ketentuan undang-undang tersebut yang terdapat dapat dalam Pasal 47 sampai Pasal 49.

Berdasarkan Peraturan Menteri Perindustrian Republik Indonesia no. 96/MIDN/PER/12/2011, AMDK memiliki definisi yang jelas, yaitu air yang telah diproses, tanpa bahan pangan lainnya dan bahan tambahan pangan, dikemas, serta aman untuk diminum. Airminum dalam kemasan yang aman, harus memenuhi persyaratan air minum dalam kemasan yang diatur sesuai dengan Standar Nasional Indonesia (SNI) Nomor SNI01-3SS3-1996. Untuk hal tersebut diperlukan pengendalian mutu dari awal sampai dengan akhir meliputi, bahan baku, proses produksinya, serta produk jadi, dalam hal ini yaitu produk AMDK.

Air minum kemasan atau dengan istilah AMDK (Air Minum Dalam Kemasan), merupakan air minum yang siap di konsumsi secara langsung tanpa harus melalui proses pemanasan terlebih dahulu. Air dalam kemasan mencakup air mineral dan air demineral. Air mineral adalah air minum dalam kemasan yang mengandung mineral dalam jumlah tertentu tanpa menambahkan mineral, sedangkan air demineral merupakan air minum dalam kemasan yang diperoleh melalui proses pemurnian seperti destilasi, reverse osmosis, dan proses setara.

Air minum dalam kemasan secara umum dapat dikelompokkan menjadi dua yaitukemasan galon (19 liter) dan small/single pack. Kemasangalon biasanya dilakukan pengisisan ulang baik oleh produsen bermerek maupun depot air minum isi ulang (tanpa merek), dan lebih banyak dikonsumsi oleh konsumen yang berada di perkantoran, hotel, dan rumah tangga.

${ }^{15}$ Susanti Adi Nugroho, Hukum Persaingan Usaha di Indonesia dalam Teori dan Praktik Serta Penerapan Hukumnya, 2012, (Jakarta: Kencana), Hlm. 701-702 
Sedangkan konsumen utama AMDK kemasan Small/single pack atau kemasan yang dapat dibawa secara praktis seperti kemasan $1500 \mathrm{ml} / 600 \mathrm{ml}$ (botol), $240 \mathrm{ml} / 220 \mathrm{ml}$ (gelas) dikonsumsi orangorang yang sedang melakukan perjalanan. ${ }^{16}$

Air adalah sebuah zat yang ada di alam yang dalam kondisi normal di atas permukaan bumi berbentuk cair, akan membeku pada suhu di bawah nol derajat celcius dan mendidih pada suhu seratus derajat celcius. Ahli kimia mendefinisikannya terdiri dari dua unsur yaitu oksigen dengan dua 'lengan' menggandeng hidrogen membentuk satu kesatuan disebut molekul. Air yang ada di alam ini pada hakekatnya semua adalah timbunan molekul- molekul yakni pasangan oksigen dan dua hidrogen. ${ }^{17}$

Air merupakan salah satu kebutuhan pokok manusia dan keberadaannya dikuasi oleh negara. Hal itu dijelaskan dalam Pasal 33 ayat (3) Undang-Undang Dasar 1945, bahwa "Bumi dan air dan kekayaan alam yang terkandung di dalamnya dikuasai oleh negara dan dipergunakan untuk sebesar-besarnya kemakmuran rakyat". Air sebagai salah satu kekayaan alam yang dilindungi negara memiliki banyak manfaat salah satunya sebagai air minum. Dalam ketentuan umum Peraturan Menteri Kesehatan RI no. 907/MENKES/SK/VII/2002 tentang syarat-syarat dan Pengawasan Kualitas Air Minum, disebutkan bahwa air minum adalah air yang melalui proses pengolahan atau tanpa proses pengolahan yang memenuhi syarat kesehatan dan dapat langsungdiminum. Air minum kemasan atau dengan istilah AMDK (Air Minum Dalam Kemasan), merupakan air minum yang siap di konsumsi secara langsung tanpa harus melalui proses pemanasan terlebih dahulu.

\section{Metode}

Karya ilmiah ini menggunakan metode analisa yuridis dan studi kepustakaan. Studi, sebagaimana dikemukakan oleh Nazir. "Studi kepustakaan adalah teknik pengumpulan data dengan mengadakan studi penelaahan terhadap buku-buku, literatur-literatur, catatancatatan, dan laporan-laporan yang ada hubungannya dengan masalah yang dipecahkan". ${ }^{18}$ Menurut Nazir studi kepustakaan merupakan langkah yang penting dimana setelah seorang penulis menetapkan topik penulisan, langkah selanjutnya adalah melakukan kajian yang berkaitan dengan teori yang berkaitan dengan topik penulisan. ${ }^{19}$ Dalam pencarian teori, penulis akan mengumpulkan informasi sebanyak-banyaknya dari kepustakaan yang berhubungan. Sumber-sumber kepustakaan dapat diperoleh dari: buku, jurnal, majalah, hasil-hasil penulisan (tesis dan disertasi), dan sumber-sumber lainnya yang sesuai (internet, koran dll). Berdasarkan teori tersebut, studi kepustakaan, merupakan daya yang diperoleh dari sumber-sumber kepustakaan. Studi kepustakaan dalam penulisan ini dimaksudkan untuk mendapatkan data-data pendukung mengenai analisis yuridis terhadap perjanjian tertutup air minum dalam kemasan (studi putusan nomor 22/KPPU-I/2016).

\section{Pembahasan Dan Hasil}

Terlapor I dalam perkara ini adalah PT Tirta Investama, yang beralamat kantor di Cyber Building, 12th Floor, Jl. HR. Rasuna Said Blok X-5 No. 13, Jakarta. Terlapor II dalam perkara ini adalah PT Balina Agung Perkasa, yang beralamat kantor di Jl. Rawabali I Nomor 1, Kawasan Industri Pulogadung, Jakarta Timur. Bahwa PT. Tirta Investama dan PT. Balina Agung Perkasa merupakan badan usaha berbentuk badan hukum. PT TIV dan

\footnotetext{
${ }^{17}$ Peraturan Menteri Perindustrian Nomor 96/M-IND/PER/12/2011 Tentang Persyaratan Teknis Air Minum dalamKemasan

${ }^{18}$ M Nazir, Metode Penulisan,1998.(Jakarta: Ghalia Indonesia), Hlm. 112.

${ }^{19} \mathrm{Ibid}$
} 


\section{PATIK : JURNAL HUKUM Vol : 09 No. 1 April 2020, Hal 51 - 59}

PT BAP secara bersama- sama pernah menyampaikan himbauan lisan kepada para pedagang SO mulai dari akhir tahun 2015 sampai dengan pertengahan tahun 2016, PT TIV melalui KAE dan PT BAP melalui bagian penjualan.

Terdapat bukti dokumen mengenai "Form Sosialisasi Pelanggan Star Outlet" yang memerintahkan bahwa penjual yang menjadi Star Outlet dari produk PT.TIV bersedia untuk tidak menjual produk air minum dalam Kemasan (AMDK) dengan merek Le Minerale, dan bersedia menerima konsekuensi sanksi dari PT. TIV berupa penurunan harga ke Wholeseller apabila menjual produk kompetitor sejenis dengan merek Le Minerale. Form Sosialisasi Pelanggan Star Outlet tersebut wajib ditandatangani oleh pedagang SO lengkap dengan nama pemilik dan nomor telepon; (Vide, Bukti Dokumen Form Sosialisasi Pelanggan Star Outlet).

Selain itu, PT BAP telah memiliki mekanisme promosi atau degradasi terhadap para pedagang dengan standar penilaian menggunakan volume penjualan sehingga adanya klausul berupa larangan menjual produk kompetitor tidak dapat dijadikan dasar untuk menurunkan (degradasi) status pedagang. Sekretariat Komisi telah melakukan penelitian tentang adanya dugaan pelanggaran Pasal 15 ayat (3) huruf b dan Pasal 19 huruf a dan b Undang-Undang Nomor 5 Tahun 1999 yang dilakukan oleh PT Tirta Investma dan PT Balina Agung Perkasa dalam Produk Air Minum dalam Kemasan Air Mineral. Sekretariat Komisi telah melakukan penyelidikan terhadap Laporan Hasil Penelitian, dan memperoleh bukti yang cukup, kejelasan, dan kelengkapan dugaan pelanggaran yang dituangkan dalam Laporan Hasil Penyelidikan. Dalam menganalisis indikasi pelanggaran yang dilakukan oleh pelaku usaha, ada dua pendekatan yaitu melalui pendekatan per se illegal dan rule of reason.

Per se illegal merupakan suatu pendekatan dimana suatu perjanjian atau suatu kegiatan bersama dilarang karena dampak dari perjanjian tersebut telah dianggap jelas dan pasti mengurangi atau menghilangkan persaingan. Oleh karena itu, dalam pendekatan ini pelaku usaha pelapor tidak perlu membuktikan adanya dampak suatu perjanjian yang dibuat oleh pelaku usaha pesaingnya. Bukti yang diperlukan adalah bahwa perjanjian yang dimaksud telah benar adanya bahwa kegiatan bisnis yang dimaksud telah benar-benar dilakukan oleh pelaku usaha pesaingnya. ${ }^{20}$ Penerapan dengan pendekatan per se illegal membawa manfaat besar bagi penegakan hukum persaingan usaha, karena pendekatan per se illegal mudah dan mempunyai kejelasan dalam proses administratif. Per se illegal yang dianggap mudah, karena memperkenankan keadilan menolak melakukan penyelidikan secara rinci yang memerlukan banyak waktu, biaya mahal untuk mencari fakta di pasar yang bersangkutan. ${ }^{21}$

Dalam Undang-Undang Nomor 5 Tahun 1999 tentang Larangan Praktek Monopoli dan/atau Persaingan Usaha Tidak Sehat, teori per se illegal diterapkan pada Pasal-Pasal yang tidak mensyaratkan "yang mengakibatkan atau dapat mengkibatkan terjadinya praktek monopoli dan/atau persaingan usaha tidak sehat". Perbuatan-perbuatan seperti perjanjian penetapan harga, perjanjian pemboikotan dan perjanjian pembagian wilayah adalah contoh jenis-jenis perbuatan yang diklafikasikan sebagai per se illegal. $^{22}$ Pendekatan rule of reason adalah kebalikan per se illegal. Pendekatan rule of reason terhadap perbuatan yang dituduhkan melanggar hukum persaingan harus mempertimbangkan situasi dan kondisi kasus, karena perbuatan yang dituduhkan tersebut

\footnotetext{
${ }^{20}$ Mustafa Kamal Rokan, Hukum Persaingan Usaha Teori Praktiknya di Indonesia, 2012, (Jakarta: Raja Grafindo Persada), Hal. 60

${ }^{21}$ Susanti Adi Nugroho, Hukum Persaingan Usaha di Indonesia dalam Teori dan Praktik Serta Penerapan Hukumnya, 2012, (Jakarta: Kencana), Hal. 701-702

${ }^{22}$ Ibid
} 
harus diteliti lebih dahulu apakah perbuatan tersebut telah membatasi persaingan secara tidak patut. Perbuatan yang diteliti dahulu, maka penggugat disyaratkan dapat menunjukkan akibat yang ditimbulkan dari perjanjian, kegiatan, dan posisi dominan yang telah menghambat persaingan atau menyebabkan kerugian.

Teori rule of reason mengharuskan pembuktian, mengevaluasi mengenai akibat perjanjian, kegiatan atau posisi dominan tertentu, guna untuk menentukan apakah perjanjian atau kegiatan tersebut menghambat atau mendukung persaingan usaha. Dalam teori rule of reason sebuah tindakan tidak secara otomatis dilarang, meskipun perbuatan yang dituduhkan tersebut kenyataannya terbukti telah dilakukan. Dengan demikian pendekatan rule of reason memungkinkan pengadilan untuk melakukan interpretasi terhadap Undang-Undang dan juga interpretasi pasar. ${ }^{23}$

Apabila Pasal 19 huruf a dan b dirumuskan secara rule of reason maka harus dibuktikan dan diuji apakah perbuatan tersebut bertujuan untuk menyingkitkan atau mematikan pesaing dan harus dievaluasi terlebih dahulu untuk melihat akibat yang ditimbulkannya terhadap persaingan dengan membuktikan apakah terjadi praktek monopoli dan atau persaingan usaha tidak sehat. Dalam kasus ini, terdapat perilaku PT. Tirta Investama dan PT. Balina Agung Perkasa yang membuat pelaku usaha pesaing terhalangi dalam mendistribusikan air minum dalam kemasan dikarenakan produk Aqua yang merupakan AMDK yang memiliki market share yang paling banyak dibandingkan dengan produk lainnya sehingga produsen dan distributor dari Aqua melarang produk pesaing dipasarkan dipasar yang sama yang dimiliki oleh produk Aqua dengan ancaman bahwa apabila tetap menjual produk tersebut mamka status dari toko tersebut akan di turunkan levelnya, bentuk lainnya adalah dengan melarang untuk tidak mendisplay produk LeMinerale. ${ }^{24}$

\section{Kesimpulan Dan Saran}

PT Balina Agung Perkasa dan PT Tirta Investama telah melakukan praktek perjanjian tertutup dan penguasaan pasar karena telah melanggar pasal 15 ayat (3) huruf b dan pasal 19 huruf a dan b. Dalam membuktikan perbuatan tersebut yang harus dilakukan adalah melihat struktur pasar, pangsa pasar, pasar bersangkutan, setelah itu baru dapat melakukan pembuktian terhadap adanya penguasaan pasar dan perjanjian tertutup. Hal tersebut berawal dari somasi yang dilakukan oleh PT Fresindo Jaya (Le Minerale) akibat larangan penjualan produk Le Minerale yang dilakukan oleh PT Tirta Investama dan PT Balina Agung (Aqua) kepada toko Star Outlet dengan ancaman degradasi toko. Bentuk penguasaan pasar yang dilakukan adalah parater lapor melakukan monitoring pada toko toko di level Star Outlet yang masih tetap menjual produk Le Minerale. Tidak hanya dengan lisan saja, namun dibuktikan dengan adanya surat pernyataan, surat elektronik, bukti komunikasi, dan sebagainya. Surat pernyataan berisi perintah yang mengharuskan untuk tidak menjual air kemasan Le Minerale.

Putusan KPPU yang telah dijatuhkan kepada PT Tirta Investama dan PT Balina Agung Perkasa telah tepat karena telah memenuhi unsur pada pasal 15 ayat (3) huruf b dan pasal 19 huruf a dan b UU No. 5 Tahun 1999. Ada baiknya agar KPPU mengkaji lebih lanjut mengenai kasus ini, karena menurut penulis sebenarnya PT Tirta Investama dan PT Balina Agung Perkasa dapat melanggar ketentuan pasal 25 UU No. 5 Tahun 1999 tentang penyalahgunaan posisi dominan. Aqua sebenarnya memiliki market power karena pangsa pasar yang paling tinggi diantara merek air minum dalam kemasan yang lain. Pemilik market power ini juga sebagai pemilik posisi dominan di pasar bersangkutan. Sebagai pemilik posisi dominan, tidak seharusnya Aqua melakukan

\footnotetext{
${ }^{23}$ Ibid, Hal. 63

${ }^{24}$ Putusan KPPU No. 22/KPPU-I/2016.
} 
perbuatan yang dapatmerugikan pelaku usaha pesaing yakni penguasaan pasar dan melakukan perjanjian tertutup.

\section{DAFTAR PUSTAKA}

\section{Buku}

Bambang, Singgono. 2010. Metode Penelitian Hukum. Jakarta: Raja Grafindo Persada. Jakarta

Departemen Pendidikan Nasional. 2012. Kamus Besar Bahasa Indonesia, Pusat Bahasa (Edisi Keempat). Jakarta: PT. Gramedia Pustaka Utama

Hermansyah. 2008. Pokok-Pokok Hukum Persaingan Usaha di Indonesia. Jakarta: Kencana

Kagramanto, L. Budi. 2008. Mengenal Hukum Persaingan Usaha Berdasarkan UU Nomor 5 Tahun 1999. Surabaya: Laros.

Lubis, Andi Fahmi. 2009. Hukum Persaingan Usaha Antara Teks \& Konteks. Jakarta: ROV Creative Media

Margono, Suyud. 2009. Hukum Anti Monopoli. Jakarta: Sinar Grafika

Nugroho, Susanti Adi. 2012. Hukum Persaingan Usaha di Indonesia dalam Teori dan Praktik Serta Penerapan Hukumnya. Jakarta: Kencana

Rokan, Mustafa Kamal. 2012. Hukum Persaingan Usaha Teori Praktiknya di Indonesia. Jakarta: Raja Grafindo Persada

Usman, Rachmadi. 2013. Hukum Persaingan Usaha di Indonesia. Jakarta: Sinar Grafika

Wiradiputra, Ditha. 2008. Perjanjian Dilarang, Bahan Mengajar Hukum Persaingan Usaha. Depok: Fakultas Hukum Universitas Indonesia.

\section{Jurnal}

Betriks Eva Kalangi. 2017. Prosedur Penanganan Perkara Monopoli Dan Persaingan Curang Serta Sanksi Hukum Terhadap Pelanggaran Undang-Undang Nomor 5 Tahun 1999. Lex Crimen Vol. VI/No. 1/Jan-Feb/ 2017

\section{Penelitian dan Tesis}

Rohim, Miftahur. 2006. Analisis Penerapan Metode Kaporitisasi Sederhana Terhadap Kualitas Bakteriologis Air PAM. Universitas Diponegoro, Fakultas Kesehatan Masyarakat

Fauziah, A. 2010. Efektivitas Saringan Pasir dalam Menurunkan Kadar Mangan (Mn) pada Air Sumur dengan Penambahan Kalium Permanganat $\left(\mathrm{KMnO}_{4}\right)$. Universitas Sumatra Utara, Fakultas Kesehatan Masyarakat.

Mandasari, R. 2010. Analisis Kadar Besi (Fe) dalam Air Minum Kemasan dengan Menggunakan Metode Spektofotometri Serapan Atom. Universitas Sumatra Utara, Fakultas Matematika dan Ilmu Pengetahuan Alam 